\title{
Unmutated Immunoglobulin Heavy Chain Variable Region Gene
}

National Cancer Institute

\section{Source}

National Cancer Institute. Unmutated Immunoglobulin Heavy Chain Variable Region

Gene. NCI Thesaurus. Code C97146.

A molecular finding indicating that the immunog lobulin heavy chain variable region has an unmutated germline configuration. 